REVIEW

\title{
Provoked vulvodynia: A peripheral neurological pain syndrome
}

\author{
(1) JACOB BORNSTEIN¹, () EILAM PALZUR² \\ 1Department of Obstetrics and Gynaecology, Galilee Medical Center and Azrieli Faculty of Medicine, Bar-Ilan University, Nahariya, Israel \\ 2The Research Institute of Galilee Medical Center and Azrieli Faculty of Medicine, Bar-Ilan University, Nahariya, Israel
}

\begin{abstract}
The main cause of vulvar pain and dyspareunia is provoked vulvodynia (PV), also known as vestibulodynia, and formerly termed "vulvar vestibulitis". It affects 8-10\% of women of all ages. Although the etiology remains an enigma, peripheral neurologic mechanism has recently been identified as a factor associated with vulvodynia. The aim of the present review is to present and discuss neuroproliferation as a main cause of PV.

Studies comparing Immunohistochemical staining of specimens from women with PV to controls, and animal models of PV, have been analysed for evidence of inflammation and neuroproliferation.

The density of nerve fibres in the vestibular stroma of women with PV was 10 times greater than that in the vestibular stroma of non-affected women controls. Moreover, the fibres penetrated the basal membrane and continued vertically, reaching close to the surface of the epithelial surface. An increase in the number of stromal mast cells has also been demonstrated in women with PV. Heparanase, discharged from mast cells, degrades the connective tissue and epithelial basement membrane, allowing the proliferating nerve fibres to penetrate the degraded epithelial basement membrane into the epithelium. This intraepithelial hyperinnervation results in local hyperesthesia characteristic of PV. In a mouse model a significant increase has been depicted in the density of nerve fibres in $40 \%$ of the mice repeatedly infected with fungal antigen. An increase in mast cells number has been depicted in a mouse model as well.
\end{abstract}

A peripheral neurologic mechanism leading to neuroproliferation has been recognised in women with PV and animal models. Future research should consider this pathogenesis.

Keywords: Provoked vulvodynia; neuroproliferation; hyperinnervation; mast cell; heparanase; vestibulectomy

\section{INTRODUCTION}

Provoked vulvodynia (PV), also called "vestibulodynia" and formerly termed "vulvar vestibulitis", is the primary cause of vulvar pain and dyspareunia. ${ }^{1}$ It affects $8-10 \%$ of women of all ages and significantly impairs their quality of life. Its most recognizable symptom is dyspareunia, and it is characterized by extreme symmetric sensitivity at the vestibule, close to the hymenal base. This concealed location of sensitivity has made diagnosis difficult and has led to myths regarding the development of PV, involving hurtful statements like "it is all in your head." Recent research has proven that the pain arises from local, organic, and vestibular sensitivity. Approximately $50 \%$ women with PV experience sensitivity only in the posterior half of the vestibule. ${ }^{2}$ The others have both anterior and posterior allodynia.

The data provided in Table 1 indicate that idiopathic vulvar pain and vulvodynia have been recognized since the first century

Address for Correspondence: Jacob Bornstein, Department of Obstetrics and Gynaecology, Galilee Medical Center and Azrieli Faculty of Medicine, Bar-Ilan University, Nahariya, Israel E-mail: mdjacob@gmail.com ORCID ID: orcid.org/0000-0003-1932-5270 Received: 20 July 2020 Accepted: 26 July 2020

${ }^{0}$ Copyright 2020 by the International Society for Pelviperineology / Pelviperineology published by Galenos Publishing House. 
AD. However, between 1928 and 1976, this syndrome was not reported in the medical literature, possibly due to ignorance owing to failure in curing vulvar pain and vulvodynia. Various treatments have been attempted for PV, but so far, the effective treatment is vestibulectomy, a surgical removal of the vestibule.

Although progress in the diagnosis and treatment of PV has been made, ${ }^{1,2}$ the etiology remains unknown. Nevertheless, a breakthrough in understanding the pathogenesis of vulvodynia was achieved with the introduction of a list of evidence-based factors associated with vulvodynia in the 2015 Consensus Terminology and Classification of Persistent Vulvar Pain and Vulvodynia (Table 2). ${ }^{3}$ Peripheral neurologic mechanism is a remarkable factor associated with vulvodynia; ${ }^{1,3}$ however, the trigger for this mechanism remains unknown. One hypothesis is that laxity of the uterosacral ligaments causes loss of support

\begin{tabular}{|l|l|}
\hline \multicolumn{2}{|l|}{ Table 1. Idiopathic vulvar pain: Historic terminologies* } \\
\hline Period, author & Term or terminology \\
\hline $\begin{array}{l}\text { First Century AD, } \\
\text { Soranus }\end{array}$ & Satyriasis in females \\
\hline 1880, Thomas & Excessive hypersensibility of the nerves \\
\hline 1889, Kellogg & Sensitive points \\
\hline 1889, Skene & Super-sensitiveness of the vulva \\
\hline 1928, Kelly & Exquisitely sensitive in hymeneal ring \\
\hline 1976, Weisfogel & The burning vulva \\
\hline 1976, ISSVD & The burning vulva syndrome \\
\hline $\begin{array}{l}\text { 1978, Dodson and } \\
\text { Friedrich }\end{array}$ & Psychosomatic vulvovaginitis \\
\hline 1978, Tovell and Young & Vulvodynia or pudendagra \\
\hline 1983, ISSVD task force & Vulvodynia or burning vulva syndrome \\
\hline 1983, Friedrich & Vestibular adenitis \\
\hline $\begin{array}{l}\text { 1983, Woodruff and } \\
\text { Parmley }\end{array}$ & $\begin{array}{l}\text { Infection of the minor vestibular } \\
\text { glands }\end{array}$ \\
\hline 1986, Peckham & Focal vulvitis \\
\hline 1987, Friedrich & Vulvar vestibulitis syndrome \\
\hline 1988, McKay & $\begin{array}{l}\text { Classification: Vestibulitis and } \\
\text { dysesthetic vulvodynia }\end{array}$ \\
\hline 1997, Bornstein & Vestibulodynia \\
\hline 1999, ISSVD & $\begin{array}{l}\text { Terminology: Generalized and localized } \\
\text { vulvar dysesthesia }\end{array}$ \\
\hline 2001, ISSVD & $\begin{array}{l}\text { Terminology: Provoked and } \\
\text { spontaneous vulvar dysesthesia, } \\
\text { each with subsets of generalized and } \\
\text { localized }\end{array}$ \\
\hline ISSVD, IPPS, & 2003 ISSVD terminology \\
\hline 2015 consensus terminology \\
\hline ISSVD
\end{tabular}

ISSVD: International Society for the Study of Vulvovaginal Disease, IPPS International Pelvic Pain Society, ISSWSH: International Society for the Study of Women's Sexual Health to the Frankenhauser's plexus, initiating the development of the pain of PV. ${ }^{4}$ The present review discusses this peripheral neurologic mechanism as a cause of PV.

\section{Peripheral neurologic findings in women with provoked vulvodynia}

As shown in Table 3, several studies have reported on hyperinnervation and nerve sprouting in the stroma of the vestibule of women with PV. ${ }^{5-15}$ The proliferating nerve fibres were reportedly nociceptors. ${ }^{16}$ Further, increased vanilloid receptor VR1 (TRPV1) density caused an increase in allodynia. ${ }^{17}$ To obtain accurate and objective quantitative data regarding hyperinnervation, we applied computerized histomorphometry to images of immunohistochemically stained sections from women with PV and controls; when the immunohistochemical S100 stain was used, the density of nerve fibres in the vestibular stroma of women with PV was 10 times greater than that in the vestibular stroma of controls. ${ }^{8}$ Moreover, these nerve fibres showed collateral sprouting that resembled nerve-ending trauma, which develops in women with chronic inflammation or major trauma such as amputation.

We have also proposed an objective histopathological criterion for establishing PV diagnosis: the total calculated area of nerve fibres (per the same microscopic field) is 10 times higher in women with PV than in controls. ${ }^{8}$ Although tissue analysis is not currently required for $\mathrm{PV}$ diagnosis, a morphological diagnosis may be useful for research purposes.

In another study, to further characterize PV hyperinnervation, we stained the tissue excised during vestibulectomy of women with

Table 2. Potential factors associated with Vulvodynia as per the 2015 Consensus Terminology and Classification of Persistent Vulvar Pain and Vulvodynia

- Comorbidities and other pain syndromes (e.g., painful bladder syndrome, fibromyalgia, irritable bowel syndrome, and temporomandibular disorder [level of evidence, 2)

- Genetics [level of evidence, 2]

- Hormonal factors (e.g., pharmacologically induced) [level of evidence, 2]

- Inflammation [level of evidence, 2]

- Musculoskeletal (e.g., pelvic muscle overactivity, myofascial, and biomechanical) [level of evidence, 2]

- Neurologic mechanisms: o Central (spinal and brain-related) [level of evidence, 2] o Peripheral neuroproliferation [level of evidence, 2]

- Psychosocial factors (e.g., mood, interpersonal, coping roles, and sexual function) [level of evidence, 2]

- Structural defects (e.g., perineal descent) [level of evidence, 3]

*The factors are listed as per alphabetical order. 
severe PV using protein gene product (PGP) 9.5. ${ }^{10}$ PGP 9.5 detects the thinnest unmyelinated sensory $C$ fibres ( $<1 \mathrm{~mm}$ thick). We demonstrated that in women with PV, the innervation not only occurred in the stroma (Figure 1a) but also penetrated the basal membrane and continued vertically for $>50 \%$ of the distance to the epithelial surface (Figure 1b), almost reaching the epithelial surface. Very thin intraepithelial nerve fibres ending within the basal layers of the epithelium were also detected. Parallel sections incubated with only secondary antiserum were not stained. Control tissues showed no intraepithelial innervation. As such, in addition to the increased density of nociceptors, the nociceptors were located much closer to the mucosal surface. This combination can explain the severe allodynia experienced by women with PV.

Women with primary PV (identified at their first attempt at intercourse or physical contact) reportedly have a higher degree of neuroproliferation than those with secondary PV. ${ }^{11}$ In such cases, the hyperinnervation may be congenital. In another study

\begin{tabular}{|c|c|c|c|c|c|c|}
\hline Authors & $\begin{array}{l}\text { Number of } \\
\text { patients }\end{array}$ & $\begin{array}{l}\text { Number of } \\
\text { controls }\end{array}$ & Type of study & NFP* in patients & NFP* in controls & p value \\
\hline $\begin{array}{l}\text { Weström and } \\
\text { Willén }^{5}\end{array}$ & 47 & 6 & Descriptive & 44 & 0 & $<0.05$ \\
\hline $\begin{array}{l}\text { Bohm-Starke } \\
\text { et al. }{ }^{6}\end{array}$ & 13 & 8 & Prospective & $5.65^{\mathrm{a}}$ & $1.125^{\mathrm{a}}$ & $<0.001$ \\
\hline $\begin{array}{l}\text { Tympanidis } \\
\text { et al. }{ }^{7}\end{array}$ & 12 & 8 & Prospective, case-control & $32.9 \pm 18.5^{b}$ & $13.0 \pm 9.2^{b}$ & 0.0015 \\
\hline $\begin{array}{l}\text { Bornstein et } \\
\text { al. }{ }^{8}\end{array}$ & 40 & 7 & $\begin{array}{l}\text { Retrospective } \\
\text { (S100 staining) }\end{array}$ & $4190 \mu \mathrm{m}^{2}$ & $425 \mu \mathrm{m}^{2}$ & 0.01 \\
\hline $\begin{array}{l}\text { Halperin et } \\
\text { al. }{ }^{9}\end{array}$ & 24 & 16 & Case-control & $19 \pm 79.1^{c}$ & $0^{c}$ & $<0.0001$ \\
\hline \multirow{2}{*}{$\begin{array}{l}\text { Bornstein et } \\
\text { al. }{ }^{10}\end{array}$} & \multirow{2}{*}{7} & \multirow{2}{*}{7} & \multirow{2}{*}{$\begin{array}{l}\text { Retrospective } \\
\text { (PGP 9.5 staining) }\end{array}$} & Intraepithelial $2.0 \pm 0$ & $0.71 \pm 0.488$ & $0.001^{\mathrm{d}}$ \\
\hline & & & & Stroma $2.0 \pm 0$ & $0.14 \pm 0.378$ & $0.001^{\mathrm{d}}$ \\
\hline \multirow{2}{*}{$\begin{array}{l}\text { Goetsch et } \\
\text { al. }^{11}\end{array}$} & 10 primary & \multirow{2}{*}{4} & \multirow{2}{*}{ Neural hyperplasia } & Primary 8 & All negative & \multirow{2}{*}{0.01} \\
\hline & 10 secondary & & & Secondary 3 & 4 & \\
\hline \multirow{2}{*}{$\begin{array}{l}\text { Leclair et } \\
\text { al. }^{12}\end{array}$} & 42 primary & \multirow{2}{*}{-} & \multirow{2}{*}{$\begin{array}{l}\text { Retrospective neural } \\
\text { hyperplasia }(0-3)\end{array}$} & \multirow{2}{*}{$\begin{array}{l}\text { Primary } \sim 2.5 \\
\text { mean }(0-3)\end{array}$} & \multirow{2}{*}{$\begin{array}{l}\text { Secondary } \sim 2.0 \\
\text { mean }(0-3)\end{array}$} & \multirow{2}{*}{$\begin{array}{l}\mathrm{OR}=3.01 \\
\mathrm{p}=0.02\end{array}$} \\
\hline & 46 secondary & & & & & \\
\hline $\begin{array}{l}\text { Brokenshire } \\
\text { et al. }{ }^{13}\end{array}$ & $\begin{array}{l}23 \text { early } \\
\text { responders }\end{array}$ & \begin{tabular}{|l|}
27 late \\
responders
\end{tabular} & Case-control & $\begin{array}{l}16.4(0-40) / \mathrm{mm}^{2} \text { (early } \\
\text { responders) }\end{array}$ & $\begin{array}{l}16.4(0-52) / \mathrm{mm}^{2} \\
\text { (late responders) }\end{array}$ & $\begin{array}{l}\text { NS } \\
\text { (only patients) }\end{array}$ \\
\hline \multirow{4}{*}{ Liao et al. ${ }^{14}$} & \multirow{2}{*}{10} & \multirow{2}{*}{7} & \multirow{2}{*}{$\begin{array}{l}\text { Case-control } \\
\text { (PGP } 9.5 \text { staining) }\end{array}$} & $\begin{array}{l}\text { Tender } \\
167 \%{ }^{\mathrm{e}}\end{array}$ & $\begin{array}{l}\text { Control } \\
100 \% \\
\end{array}$ & 0.021 \\
\hline & & & & $\begin{array}{l}\text { Tender } \\
169 \% \\
\end{array}$ & $\begin{array}{l}\text { Non-tender } \\
100 \%\end{array}$ & 0.027 \\
\hline & \multirow{2}{*}{5} & \multirow{2}{*}{5} & \multirow{2}{*}{$\begin{array}{l}\text { Case-control } \\
\text { (TRPV4 axon density) }\end{array}$} & $\begin{array}{l}\text { Tender } \\
139 \%\end{array}$ & $\begin{array}{l}\text { Control } \\
100 \%\end{array}$ & 0.011 \\
\hline & & & & $\begin{array}{l}\text { Tender } \\
115 \% \\
\end{array}$ & $\begin{array}{l}\text { Non-tender } \\
100 \%\end{array}$ & 0.002 \\
\hline \multirow{2}{*}{$\begin{array}{l}\text { Tommola et } \\
\text { al. }{ }^{15}\end{array}$} & 27 & 15 & $\begin{array}{l}\text { Case-control } \\
\text { (PGP } 9.5 \text { staining) }\end{array}$ & $6.3(0.0-15.8) / \mathrm{mm}$ & $2.0(0.0-12.0) / \mathrm{mm}$ & 0.006 \\
\hline & & & $\begin{array}{l}\text { Case-control } \\
\text { (NF2F11 staining) }\end{array}$ & $63.0 \%$ & $0.0 \%$ & - \\
\hline \multicolumn{7}{|c|}{$\begin{array}{l}\text { NFP: Nerve fibre proliferation, PGP: Protein gene product, OR: Odds ratio, NS: Not significant, TRPV4: Transient receptor potential vanilloid-4, NF2411: } \\
\text { Neuron specific neurofilament, SD: Standard deviation } \\
\text { aValues are expressed as mean number of nerve fibres per section. } \\
\text { bValues are expressed as mean } \pm \text { SD. Area is expressed as } \mu \mathrm{m} 2 \text { of immunostaining. } \\
\text { cValues are expressed as mean } \pm \text { SD, calculated per } 10 \text { high power fields (HPFs). Nerve fibre area was an independent variable significantly associated with } \\
\text { provoked vulvodynia. } \\
\text { dSemi-quantification, } 0-3 \text {; result in mean } \pm \text { SD. } \\
\text { eValues are expressed in percentage increase of nerve fibre number }\end{array}$} \\
\hline
\end{tabular}


involving 10 women with PV, sensitive areas contained increased numbers of mechanoreceptive nociceptor axons relative to nontender foci and to that in 7 controls. ${ }^{14}$ The sensitive areas also contained increased T-cell, macrophage, and B-cell numbers. Local renin-angiotensin system protein levels were increased because more T-cells and B-cells expressed angiotensinogen. In another study, the hyperinnervation was more pronounced in foci with marked B-cell but not T-cell infiltration. ${ }^{15}$

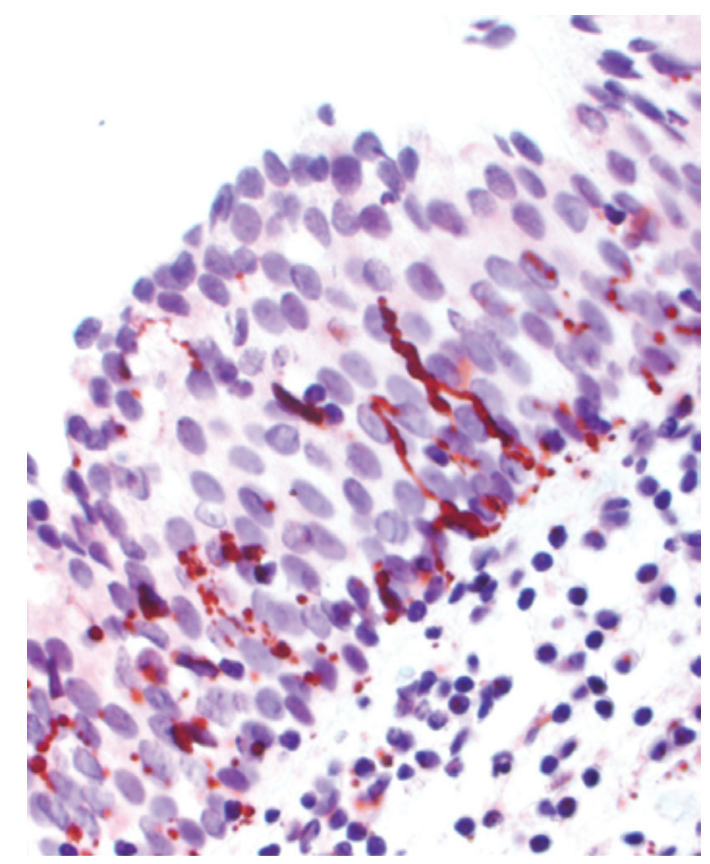

Figure 1a. PGP 9.5 stain in a tissue specimen from a woman with provoked vulvodynia showing nerve fibres intruding into the epithelium to $>50 \%$ of its depth. Magnification: $\times 400$ PGP: Protein gene product

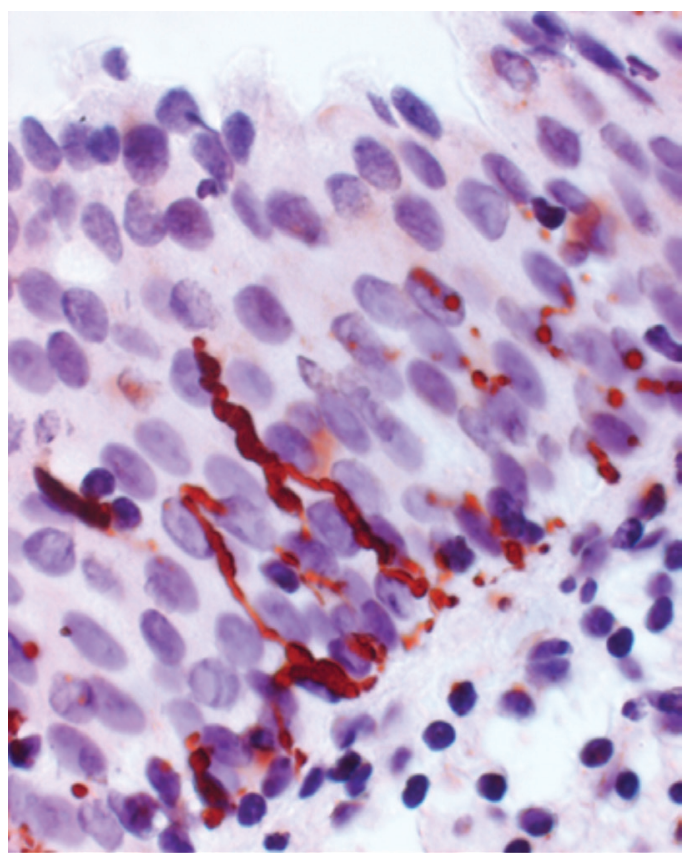

Figure $1 \mathrm{~b}$. Same as Figure 1a, but with magnification: $\times 600$

\section{Inflammation and provoked vulvodynia}

Acute inflammation may lead to chronic sensitization that persists even after the inflammation resolves. ${ }^{18,20}$ However, results regarding cytokine, prostaglandin E2 levels, T-cell, B-cell, natural killer cell, and macrophage numbers have been inconsistent in women with PV. ${ }^{21}$ Studies on proinflammatory vaginal or plasma cytokine profiles in vulvodynia are ongoing. $22-24$

Some women with vulvodynia have reported recurrent yeast infections; ${ }^{25}$ this, together with the reduced systemic number of natural killer cells in women with vulvodynia compared with that in controls, ${ }^{26}$ led to the hypothesis that deficiency in natural killer cell numbers is correlated with recurrent Candida infections in these women. Vulnerability to Candida infection associated with the reduced capability to stop the resulting inflammation has been described; however, a causal relationship between Candida infection and vulvodynia development cannot be determined via these observations.

\section{Mast cells and hyperinnervation}

Findings concerning hyperinnervation in women with PV prompted a search for agents that could enhance nerve growth. One of the potential agents may be mast cells. Mast cells discharge various mediators from their granules, such as histamine, tryptase, nerve growth factor (NGF), and bradykinin. ${ }^{27,28}$ Some of these directly cause pain, whereas the others cause pain by stimulating peripheral neurons. An increase in the number of mucosal mast cells has been demonstrated in women with $\mathrm{PV},{ }^{29}$ ${ }^{31}$ and in an animal model of vulvodynia. ${ }^{32}$ We assessed women with severe PV undergoing vestibulectomy and compared them with those of a similar age undergoing vestibular biopsy due to other conditions. ${ }^{33}$ Mast cell detection was conducted not only using Giemsa stain (Figure 2) but also immunostaining for c-KIT (Figure 3) and mast cell tryptase. ${ }^{8,10,33} \mathrm{c}-\mathrm{KIT}$ is a membrane protooncogene encoding a type 3 tyrosine kinase protein receptor. In contrast, tryptase is a specific protein present in granules secreted from mast cells. Positive tryptase staining indicates that the mast cells were activated and degranulated. Using both c-KIT and tryptase staining, we observed a significant number of mast cells in the superficial dermis, mostly activated, in women with PV compared to that in controls. An increase in the number of stromal mast cells has also been demonstrated in animal models of PV. ${ }^{29-31}$ In another study, although the number of mast cells was not increased, they were activated in sensitive vestibular areas, as indicated via chymase discharge. ${ }^{14}$ Chymase is one of three peptidases capable of converting angiotensin I to angiotensin II, which is a promoter of axon sprouting and regeneration. ${ }^{34}$

While some studies have not demonstrated an increase in mast cell numbers in women with PV, these studies were limited 


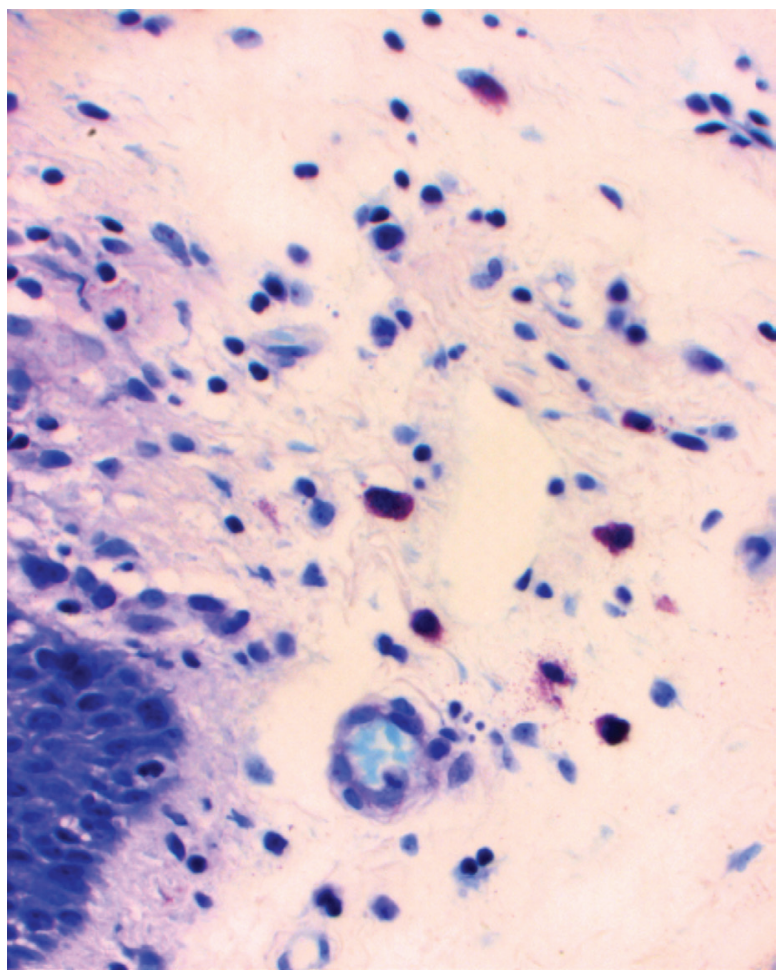

Figure 2. Giemsa staining of a specimen from a woman with provoked vulvodynia showing mast cells in the subepithelium. Magnification: $\times 600$

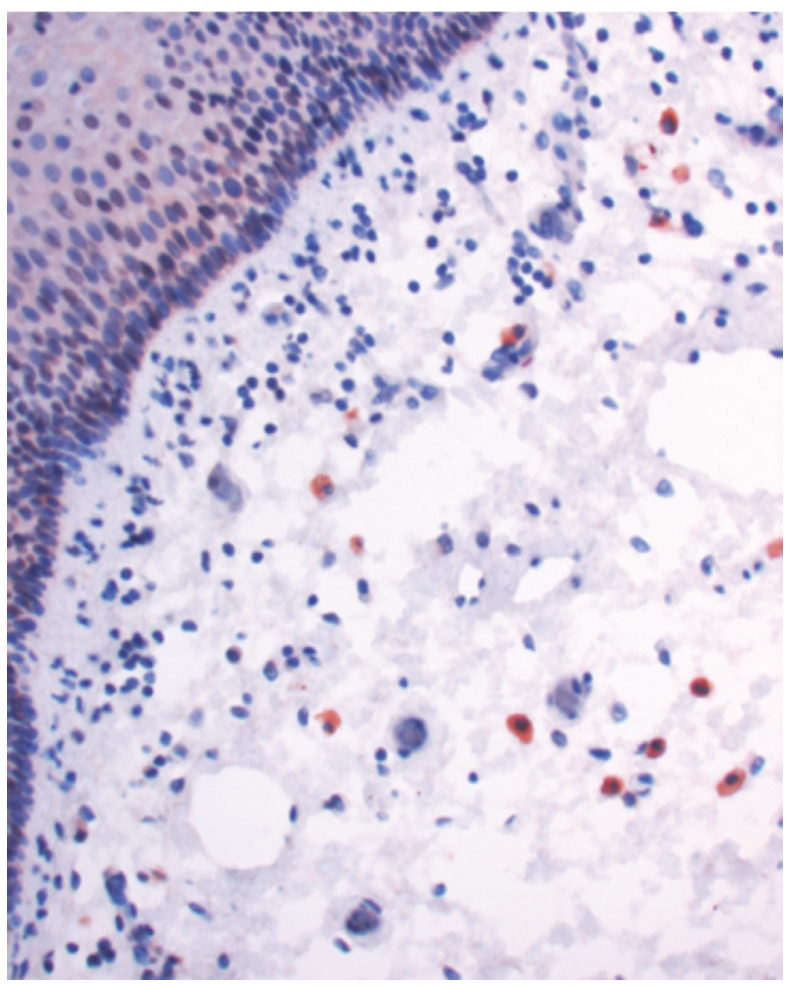

Figure 3a. CD117 (c-KIT) staining in a specimen from a woman with provoked vulvodynia showing mast cells in the subepithelium, among other inflammatory cells. Magnification: $\times 400$

C-KIT: gene encoding the receptor tyrosine kinase protein known as tyrosine-protein kinase, CD117: Cluster of differentiation 117 because they only used Giemsa staining or c-KIT staining but not a marker of mast cell activation, such as tryptase. ${ }^{35}$ Another limitation was that these studies sampled only one fixed area of the vestibule, regardless of whether that focus was sensitive. In another study that compared tender and non-tender foci, mast cell numbers were significantly increased in the tender foci. ${ }^{11}$

Heparanase (HPSE) is another enzyme secreted by mast cell granules. ${ }^{36}$ We immunostained surgical specimens from women undergoing vestibulectomy and from controls for HPSE and demonstrated the presence of this enzyme in the subepithelial cells of the vestibule in women with PV (Figure 4). ${ }^{10,33}$ HPSE is a mammalian endoglycosidase (endo-alpha-D-glucuronidase) that can cleave heparan sulfate, a proteoglycan that stabilizes the connective tissues, ${ }^{36}$ thereby releasing heparin-binding growth factors, enzymes, and plasma proteins that further weaken the extracellular matrix. Conceivably, HPSE degrades the connective tissue and epithelial basement membrane, allowing proliferating nerve fibres to penetrate the degraded epithelial basement membrane to the epithelial surface. This intraepithelial hyperinnervation results in local hyperesthesia characteristic of PV.

This proposed mechanism raised the hypothesis that blocking HPSE activity might halt PV development. Such blockade may be achieved by an anti-HPSE agent such as unfractionated or low-molecular-weight heparin; heparin is reportedly a powerful inhibitor of the activity of HPSE on antithrombin-binding

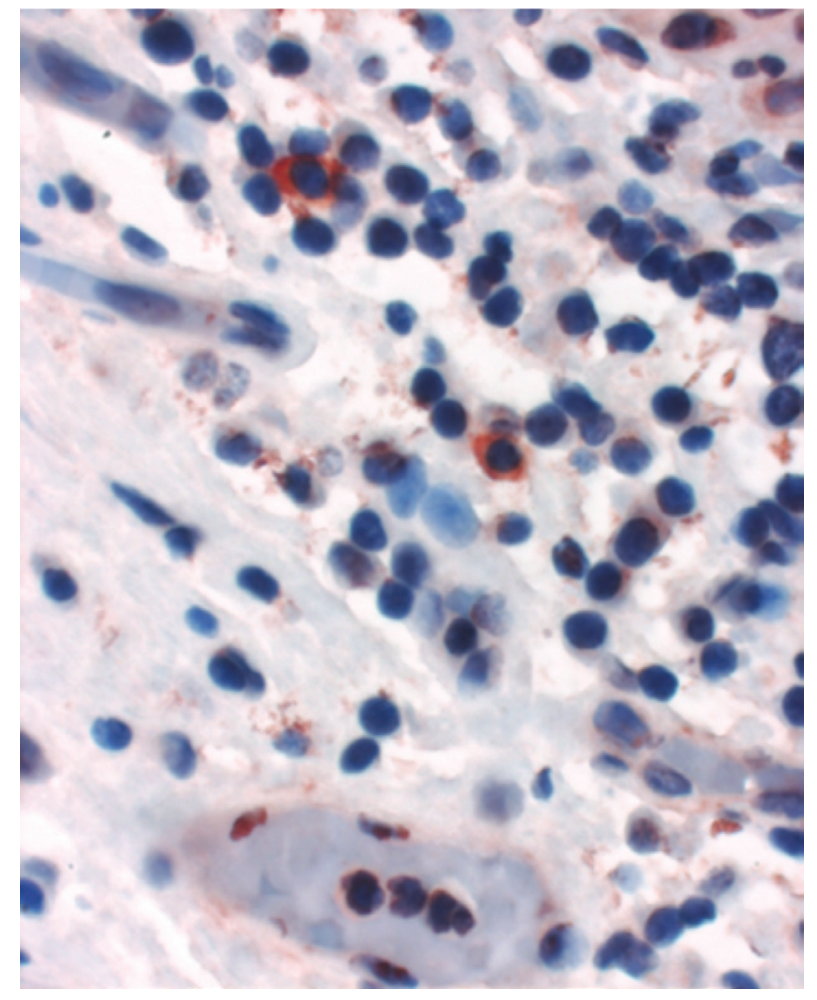

Figure 3b. Same as Figure 3a, Magnification: $\times 600$ 
oligosaccharides. ${ }^{37}$ We therefore conducted a randomized controlled trial of an anti-HPSE agent (enoxaparin) for the treatment of $\mathrm{PV}^{33}$ This treatment led to a greater reduction of clinical and subjective pain scores in women treated with

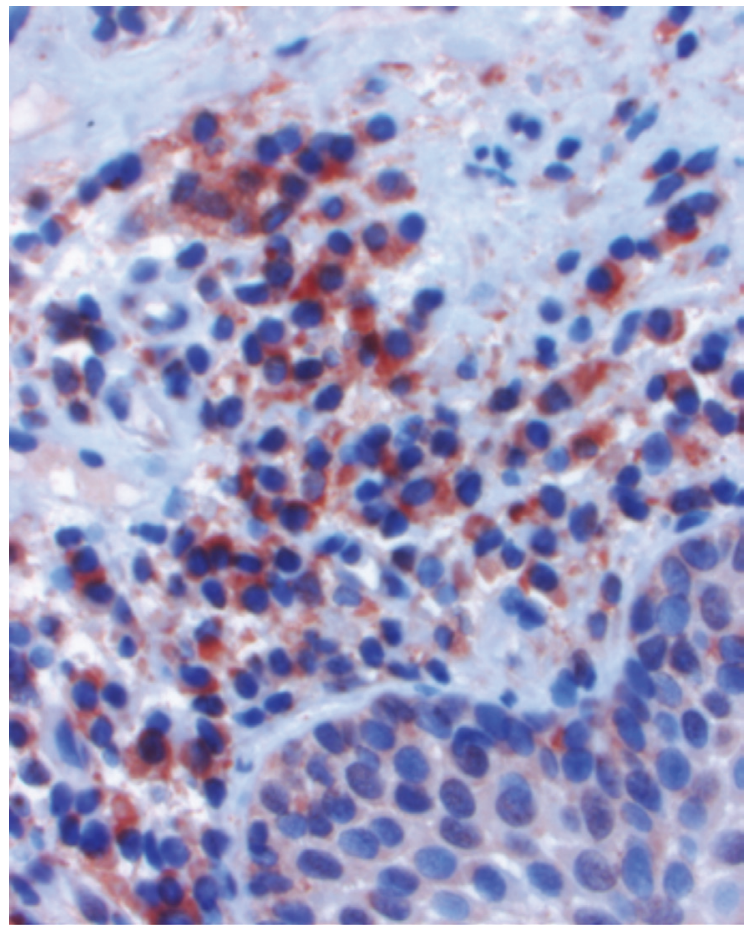

Figure 4a. Heparanase expression in a specimen from a woman with provoked vulvodynia. Positive cytoplasmic staining is seen in the subepithelial layer, close to the epithelial basement membrane. Magnification: $\times 400$

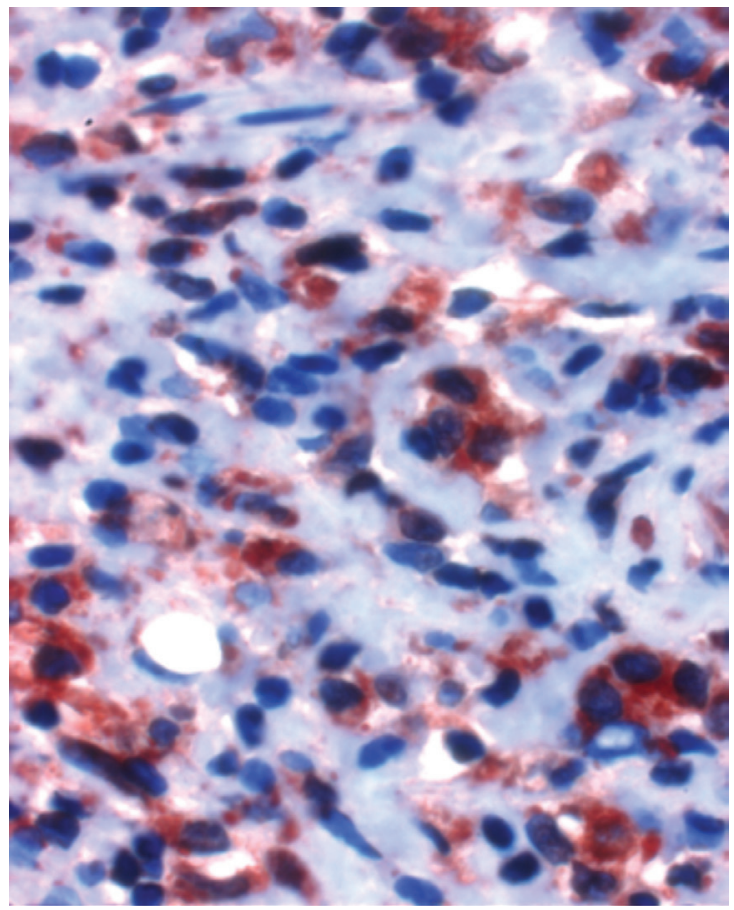

Figure 4b. Same as Figure 4a, Magnification: $\times 600$ enoxaparin than in a placebo-controlled group. Pain reduction was correlated with a diminishing number of intraepithelialfree nerve fibres in the enoxaparin group but not in the placebo group. ${ }^{33}$ The anti-HPSE therapy may have worked by strengthening the stroma, thereby inhibiting neuronal sprouting and proliferation.

\section{Genetic predisposition to neuroproliferation and provoked vulvodynia}

Consequent to our studies associating mast cell increase and activation, HPSE excretion, and hyperinnervation with vulvodynia, we examined a possible genetic predisposition of women with PV to these phenomena. ${ }^{38}$ We examined several single nucleotide polymorphisms (SNPS) in TRPV1, NGF, and HPSE genes in 65 women with moderate or severe primary PV, comparing them to 126 healthy, ethnically matched controls. Genotyping analyses revealed a novel, statistically significant and elevated prevalence of SNPs in TRPV1 and in the promoter region of NGF in women with PV than in controls. The amino acid substitution resulting from SNPs in TRPV1 modifies the functional properties of the channel and induces increased TRPV1 protein expression due to an increased copy number. ${ }^{39}$ Women with PV exhibit lower thresholds for heat pain as well as increased expression of the receptor. ${ }^{17,40}$

Our finding of a polymorphism in NGF is further supported by another study that demonstrated increased blood levels of NGF in response to Candida antigen stimulation in women with vulvodynia than in controls. ${ }^{41}$ In another study, an increase in NGF levels was detected in vestibular tissues from women with $\mathrm{PV}$, but only in areas with abundant B-cells. ${ }^{15} \mathrm{NGF}$ plays a role in the development of peripheral nerves by promoting neuronal growth and survival. ${ }^{42,43}$ NGF produces pain directly by acting on the nerves and indirectly by affecting mast cells. ${ }^{44}$ NGF also increases TRPV1 expression. ${ }^{45}$ Additionally, hyperalgesia was shown to be extensively mediated by NGF-positive regulation of the TRPV1-promoter system via Sp1 and Sp4 transcription factors. ${ }^{34,46}$

\section{Animal models of provoked vulvodynia}

Animal models of PV have been developed to monitor the progression of PV. Hyperinnervation has been elicited in the vestibule of mice and rodents in which vulvodynia was induced via various topical vestibular stimuli. Hyperinnervation persisted even after the initial local inflammatory reaction subsided. In an established mouse model, ${ }^{47}$ a significant increase in the density of nerve fibres, immunostained by PGP 9.5, developed in $40 \%$ of the mice repeatedly infected with Candida albicans strain SC5314 or by zymosan (a mixture of fungal antigens). There was 
a $300-400 \%$ increase in the number of nerve fibres in the mice that developed hyperinnervation. Furthermore, an elevation in the density of peptidergic fibres, as revealed by calcitonin generelated peptide (CGRP) levels was depicted in the allodynic group. The hyperinnervation was observed throughout the lamina propria, with some thin nerves penetrating the lamina propria beneath the epithelium. An increase in sympathetic innervation, as revealed by the vesicular monoamine transporter 2 levels, was shown in allodynic mice. No inflammation was noted in the tissues. The finding of hyperinnervation and allodynia in only $40 \%$ of the treated mice was attributed to the variable genetic predisposition of the mice to vulvodynia.

In another mouse vulvodynia model, allodynia was achieved through topical application of the proinflammatory hapten oxazolone. ${ }^{48}$ In oxazolone-sensitized female ND4 Swiss mice, a single labial oxazolone challenge provoked vulvar mechanical hyperalgesia for up to $24 \mathrm{~h}$. This was accompanied by neutrophil influx, increased inflammatory cytokine gene expression, and increased density of cutaneous CGRP and PGP 9.5-immunostained nerve fibres. Moreover, a 3-day consecutive oxazolone challenge caused vulvar hyperalgesia that was persistent for up to 5 days, even after the initial local inflammatory reaction subsided.

In another study performed by the same group ${ }^{49}$ oxazolonechallenged mice developed significant tactile hypersensitivity that persisted for $>3$ weeks, even after exposure to vestibular allergen was discontinued. The hypersensitivity only disappeared 6 weeks after the exposure. In the allergen-challenged mice, $>3$-fold increase in cutaneous vestibular CGRP nerve intensity was detected compared with that in vehicle-challenged and untreated controls. A 10-fold increase was noted in RNA expression for transcripts encoding NGF and the nerve/mast cell synapse marker cell adhesion molecule 1 . This indicates that the local environment supported neuronal growth and maintenance. These sites were characterized by increases in mast cell numbers as well as regulatory CD4, CD25, FoxP3, and T cell infiltration. Local depletion of mast cells by intralabial administration of the mast cell degranulation compound $48 / 80$ led to reduction in both nerve density and tactile sensitivity.

In a placebo-controlled study, ${ }^{50}$ an increased number of CD68immunoreactive cells was demonstrated in the distal vagina of C57BL/6 mice after microinjection of complete Freund's adjuvant (CFA) versus saline. Inflammation and innervation density were assessed at 7 and 28 days following the single administration or 14 days following the repeated administration of CFA or saline. Increased mast cell numbers were demonstrated. Hyperinnervation was evident in CFA mice via staining with PGP 9.5, CGRP, substance P, vasoactive intestinal peptide, and neuropeptide $Y$.

\section{DISCUSSION}

The 2015 Consensus Terminology and Classification of Persistent Vulvar Pain and Vulvodynia regards the peripheral neurologic mechanism as one of several factors associated with vulvodynia. ${ }^{3}$ The data reviewed in this study support the hypothesis that neuropathy or hyperinnervation is the actual cause of allodynia in women with PV. Several groups, including ours, have successfully shown that neuroproliferation developed only in women with PV and not in healthy women. Subsequently, removal of the hyperinnervated tissue may explain the successful outcome of the surgical excision of the vestibule-vestibulectomy, in women with PV. Non-invasive treatment approaches, aiming at preventing or reducing the effect of hyperinnervation may be developed in the future.

In animal models, hyperinnervation persisted for many days, even after the topical application of an anti-irritant and the initial local inflammatory reaction subsided. In terms of the etiopathogenesis of neuroproliferation, several researchers have demonstrated a correlation between hyperinnervation and the increased presence of mast cells in local tissues and their activation in women with PV. Consequently, we hypothesized that mast cell activation triggers the increase in the numbers of nerve fibres, with granule discharge of various mediators such as NGF, histamine, bradykinin, tryptase, prostaglandins, serotonin, and leukotriene. These mediators can sensitize $C$ fibres and induce their proliferation, causing pain. NGF may be secreted by both mast cells and neurons and can induce neuronal growth and reduce the subsequent neuronal firing threshold causing increased pain perception. ${ }^{29}$ The SNPs in NGF and TRPV1 demonstrated by us may be the reason for the uncontrolled production of NGF, leading to excessive neuroproliferation in some women with PV. This is a vicious cycle as NGF also attracts mast cells and stimulates its own synthesis via NGF receptors on the mast cell membranes and nerves alike. Nerve sprouting and penetration of the newly formed nerve fibres into the epithelium is then made possible by HPSE.

Alternatively, another potential etiological mechanism for the increased mast cell numbers in women with PV is neurogenic inflammation. In this regard, stimulated nociceptors cause neurons to discharge neuropeptides that draw and stimulate local mast cells. Indeed, electron microscopic studies have shown that mast cells are closely related to sensory nerve fibres containing neuropeptides that induce mast cell degranulation. A similar mechanism has been reported in interstitial cystitis/bladder pain syndrome, a condition that may occur simultaneously with PV.

In addition, pelvic organ prolapse has been associated with vulvodynia. ${ }^{51}$ Further studies may explore the association between 
pelvic organ prolapse, laxity of the uterosacral ligaments and PV, and possibly the peripheral neurologic mechanism of PV.

\section{CONCLUSION}

In conclusion, vestibular neuroproliferation has been repeatedly depicted to be a substantial associated factor of PV.

\section{ETHICS}

Peer-review: Externally peer-review.

\section{DISCLOSURES}

Conflict of Interest: There are no conflicts of interest to declare.

Financial Disclosure: The authors declared that this study received no financial support.

\section{REFERENCES}

1. Bornstein J. Chapter 54 - Vulvar Pain and Vulvodynia. In: Bornstein J, ed. Vulvar Disease. 2019; 343-367. 1st ed. Cham Switzerland: Springer Nature.

2. Bornstein J, Abramovici H. Combination of sub-total perineoplasty and interferon for vulvar vestibulitis: a comparative study. Gynecol Obstet Invest 1997; 44: 53-6.

3. Bornstein J, Goldstein AT, Stockdale CK, et al. 2015 ISSVD, ISSWSH and IPPS consensus terminology and classification of persistent vulvar pain and vulvodynia. Obstet Gynecol 2016; 127: 745-51.

4. Petros PE. Severe chronic pelvic pain in women may be caused by ligamentous laxity in the posterior fornix of the vagina. Aust NZ J Obstet Gynaecol 1996; 36: 351-4.

5. Weström LV, Willén R. Vestibular nerve fiber proliferation in vulvar vestibulitis syndrome. Obstet Gynecol 1998; 91: 572-6.

6. Bohm-Starke N, Hilliges M, Falconer C, Rylander E. Increased intraepithelial innervation in women with vulvar vestibulitis syndrome. Gynecol Obstet Invest 1998; 46: 256-60.

7. Tympanidis P, Terenghi G, Dowd P. Increased innervation of the vulval vestibule in patients with vulvodynia. $\mathrm{Br}$ J Dermatol 2003; 148: 1021-7.

8. Bornstein J, Goldschmid N, Sabo E. Hyperinnervation and mast cell activation may be used as histopathologic diagnostic criteria for vulvar vestibulitis. Gynecol Obstet Invest 2004; 58: 171-8.

9. Halperin R, Zehavi S, Vaknin Z, Ben-Ami I, Pansky M, Schneider D. The major histopathologic characteristics in the vulvar vestibulitis syndrome. Gynecol Obstet Invest 2005; 59: 75-9.

10. Bornstein J, Cohen Y, Zarfati D, Sela S, Ophir E. Involvement of heparanase in the pathogenesis of localized vulvodynia. Int J Gynecol Pathol 2008; 27: 136-41.

11. Goetsch MF, Morgan TK, Korcheva VB, Li H, Peters D, Leclair CM. Histologic and receptor analysis of primary and secondary provoked vulvodynia and controls: a prospective study. Am J Obstet Gynecol 2010; 202: 614.e1-8.

12. Leclair CM, Goetsch MF, Korcheva VB, Anderson R, Peters D, Morgan TK. Differences in primary compared with secondary provoked vulvodynia in immunohistochemistry. Obstet Gynecol 2011; 117: 1307-13.

13. Brokenshire C, Pagano R, Scurry J. The value of histology in predicting the effectiveness of vulvar vestibulectomy in provoked provoked vulvodynia. J Low Genit Tract Dis 2014; 18: 109-14.

14. Liao Z, Chakrabarty A, Mu Y, et al. A Local Inflammatory ReninAngiotensin System Drives Sensory Axon Sprouting in Provoked Vestibulodynia. J Pain 2017; 18: 511-25.

15. Tommola P, Unkila-Kallio L, Paetau A, Meri S, Kalso E, Paavonen J. Immune activation enhances epithelial nerve growth in provoked provoked vulvodynia. Am J Obstet Gynecol 2016; 215: 768.e1-8.

16. Bohm-Starke N, Hilliges M, Falconer C, Rylander E. Neurochemical characterization of the vestibular nerves in women with vulvar vestibulitis syndrome. Gynecol Obstet Invest 1999; 48: 270-5.

17. Tympanidis P, Casula MA, Yiangou Y, Terenghi G, Dowd P, Anand P. Increased vanilloid receptor VR1 innervation in vulvodynia. Eur J Pain 2004; 8: 129-33.

18. Sutton KS, Yessick LR, Wild CJ, Chamberlain SM, Pukall CF. Exploring the neural correlates of touch and pain in women with provoked vestibulodynia. Pain 2020; 161: 926-37.

19. Ji RR, Xu ZZ, Gao YJ. Emerging targets in neuroinflammation-driven chronic pain. Nat Rev Drug Discov 2014; 13: 533-48.

20. Pukall CF, Goldstein AT, Bergeron S, et al. Vulvodynia: definition, prevalence, impact, and pathophysiological factors. J Sex Med 2016;13: 291-304.

21. Chalmers KJ, Madden VJ, Hutchinson MR, Moseley GL. Local and systemic inflammation in localized, provoked vestibulodynia: a systematic review. Obstet Gynecol 2016; 128: 337-47.

22. Gerber S, Witkin SS, Stucki D. Immunological and genetic characterization of women with vulvodynia. J Med Life 2008; 1: 432-8.

23. Reed BD, Plegue MA, Sen A, Haefner HK, Siddiqui J, Remick DG. Nerve growth factor and selected cytokines in women with and without vulvodynia. J Low Genit Tract Dis 2018; 22: 139-46.

24. Zanotta N, Campisciano G, Scrimin F, et al. Cytokine profiles of women with vulvodynia: Identification of a panel of proinflammatory molecular targets. Eur J Obstet Gynecol Reprod Biol 2018; 226: 66-70

25. Harlow BL, Caron RE, Parker SE, Chatterjea D, Fox MP, Nguyen RH. Recurrent yeast infections and vulvodynia: can we believe associations based on self-reported data? J Women's Health 2017; 26: 1069-76.

26. Masterson BJ, Galask RP, Ballas ZK. Natural killer cell function in women with vestibulitis. J Reprod Med 1996; 41: 562-8.

27. Letourneau R, Pang X, Sant GR, Theoharides TC. Intragranular activation of bladder mast cells and their association with nerve processes in interstitial cystitis. Br J Urol 1996; 77: 41-54.

28. Schmelz M, Zeck S, Raithel M, Rukwied R. Mast cell tryptase in dermal neurogenic inflammation. Clin Exp Allergy 1999; 29: 695-702.

29. Chadha S, Gianotten WL, Drogendijk AC, Weijmar Schultz WC, Blindeman LA, van der Meijden WI. Histopathologic features of vulvar vestibulitis. Int J Gynecol Pathol 1998; 17: 7-11.

30. Chaim W, Meriwether C, Gonik B, Qureshi F, Sobel JD. Vulvar vestibulitis subjects undergoing surgical intervention: a descriptive 
analysis and histopathological correlates. Eur J Obstet Gynecol Reprod Biol 1996; 68: 165-8.

31. Regauer S, Eberz B, Beham-Schmid C. Mast cell infiltrates in vulvodynia represent secondary and idiopathic mast cell hyperplasias. APMIS 2015; 123: 452-6.

32. Landry J, Martinov T, Mengistu H, et al. Repeated hapten exposure induces persistent tactile sensitivity in mice modeling localized provoked vulvodynia. PLoS One 2017; 12: e0169672.

33. Farajun Y, Zarfati D, Abramov L, Livoff A, Bornstein J. Enoxaparin treatment for vulvodynia: a randomized controlled trial. Obstet Gynecol 2012; 120: 565-72.

34. Cote F, Do TH, Laflamme L, Gallo JM, Gallo-Payet N. Activation of the AT(2) receptor of angiotensin II induces neurite outgrowth and cell migration in microexplant cultures of the cerebellum. J Biol Chem 1999; 274: 31686-92.

35. Papoutsis D, Haefner HK, Crum CP, Opipari AW Jr, Reed BD. Vestibular mast cell density in vulvodynia: a case-controlled study. J Low Genit Tract Dis 2016; 20: 275-9.

36. Bashkin P, Razin E, Eldor A, Vlodavsky I. Degranulating mast cells secrete an endoglycosidase that degrades heparan sulfate in subendothelial extracellular matrix. Blood 1990; 75: 2204-12.

37. Rose M, Page CP. Glycosaminoglycans and the regulation of allergic inflammation. Curr. Drug Targets Inflamm Allergy 2004; 3: 221-5.

38. Kalfon L, Azran A, Farajun Y, et al. Localized provoked vulvodynia: association with nerve growth factor and transient receptor potential vanilloid type 1 genes polymorphisms. J Low Genit Tract Dis 2019; 23: 58-64.

39. Winter Z, Buhala A, Ötvös F, et al. Functionally important amino acid residues in the transient receptor potential vanilloid 1 (TRPV1) ion channel: an overview of the current mutational data. Mol Pain 2013; 9: 30 .

40. Amaya F, Shimosato G, Nagano M, et al. NGF and GDNF differentially regulate TRPV1 expression that contributes to development of inflammatory thermal hyperalgesia. Eur J Neurosci 2004; 20: 230310.

41. Reed BD, Plegue MA, Sen A, Haefner HK, Siddiqui J, Remick DG. Nerve growth factor and selected cytokines in women with and without vulvodynia. J Low Genit Tract Dis 2018; 22: 139-46.

42. Skaper SD. The biology of neurotrophins, signaling pathways, and functional peptide mimetics of neurotrophins and their receptors. CNS Neurol Disord Drug Targets 2008; 7: 46-62.

43. Mantyh PW, Koltzenburg M, Mendell LM, Tive L, Shelton DL. Antagonism of nerve growth factor-TrkA signaling and the relief of pain. Anesthesiology 2011; 115: 189-204.

44. Woolf CJ, Safieh-Garabedian B, Ma QP, Crilly P, Winter J. Nerve growth factor contributes to the generation of inflammatory sensory hypersensitivity. Neuroscience 1994; 62: 327-31.

45. Schwartz ES, Xie A, La JH, Gebhart GF. Nociceptive and inflammatory mediator upregulation in a mouse model of chronic prostatitis. Pain 2015; 156: 1537-44.

46. Chu C, Zavala K, Fahimi A, et al. Transcription factors Sp1 and Sp4 regulate TRPV1 gene expression in rat sensory neurons. Mol Pain 2011; $7: 44$.

47. Farmer MA, Taylor AM, Bailey AL, et al. Repeated vulvovaginal fungal infections cause persistent pain in a mouse model of vulvodynia. Sci Transl Med 2011; 3: 101 ra91.

48. Martinov T, Glenn-Finer R, Burley S, et al. Contact hypersensitivity to oxazolone provokes vulvar mechanical hyperalgesia in mice. PLoS One 2013; 8: e78673.

49. Landry J, Martinov T, Mengistu H, et al. Repeated hapten exposure induces persistent tactile sensitivity in mice modeling localized provoked vulvodynia. PLoS One 2017; 12: e0169672.

50. Sharma H, Ji E, Yap P, et al. Innervation changes induced by inflammation in the murine vagina. Neuroscience 2018; 372: 16-6.

51. Bornstein J. The consensus terminology of persistent vulvar pain and vulvodynia. Pelviperineology 2018; 37: 3-5. 